\title{
Structural Social Capital Studies in Management and Organization Literature: A Bibliometric Network Study
}

\author{
Hale Alan' ${ }^{1}$, Ali Riza Köker²
}

Submitted: 29.03.2021. Accepted: 13.06.2021

\section{Abstract}

Purpose: Many empirical and review studies have been performed in the management and organization literature from the structural social capital perspective. Since these studies focus on different topics periodically, we aimed to make a bibliometric analysis of the structural social capital literature that allows a regular, systematic, and quantitative evaluation of published articles in management and organization science to identify the underlying structure in this research area and to identify the main research themes of the scholarship.

Methodology: The bibliographic matching technique was used for checking international databases to explore the main concepts and themes of the management and organization literature and to identify main themes in the research area. Therefore, this article offers a bibliometric analysis of the literature that allows for a regular, systematic, and quantitative evaluation of published articles to identify their underlying structure and to identify the main research themes in the scholarship. Research data were analyzed using the text mining method, which is a sub-branch of the data mining method and one of the most critical ways to analyze and process unstructured data.

Findings: Structural social capital studies were examined in management and organization science databases in three periods forming four years. Although there are no completely different emerging themes, we noticed periodic differences and change in priority rankings. Moreover, we found that the subjects repeat every period with few new concepts.

Implications: This research shows the main themes in the management and organization literature, where structural social capital elements are examined together, and covers all areas of management, organization and business science. Considering the main topics of the three periods of this research, there are similarities, namely the words that rank among the top in each period are "innovation," "entrepreneurship," "knowledge management," "performance," "leadership," "technology," and "human resources" and these themes are the most prominent.

Originality/Value: This research presents an overview of all past studies that focus on the structural social capital present in social interactions. Since structural social capital influences management and organization literature, it is considered a valuable study and a guide for future research.

Keywords: structural social capital, management, organization, bibliometricstructural social capital, management, organization, bibliometric.

\section{JEL: M12, M19, D85}

\footnotetext{
1 Corresponding author, Akdeniz University, Management Information Systems, 07600, Antalya, Manavgat, Turkey; e-mail: halealan@akdeniz. edu.tr; http://orcid.org/0000-0002-2444-1551.

2 Turkish Patent and Trademark Office, Ankara, Turkey, e-mail: alikoker@gmail.com; https://orcid.org/0000-0002-8171-4368.
} 


\section{Introduction}

Social capital has been working extensively and widely in the field of management and organization for the last two decades due to its importance for organizations and societies. Social capital is linked with the features of social organization such as networks, norms, and social trust that facilitate coordination and cooperation for mutual benefit (Putnam, 1995, p. 67). Inkpen and Tsang (2005, p. 151) define social capital as the sum of the resources that an individual or organization obtains from established network relationships. Walker, Kogut, and Shan (1997) state that social capital exists in network settings and brings opportunities for entrepreneurial activities. According to the most widely accepted definition, "social capital is the totality of resources associated with having a network of institutionalized relationships based on mutual acquaintance or awareness of each other" (Bourdieu, 1986, p. 248). From this viewpoint, social capital represents an actor's ability to benefit from its membership in a social network or another social structure (Coleman, 1988; Burt, 1992). Therefore, social capital is seen as a valuable resource for individuals and social groups (Nahapiet and Ghoshal, 1998).

Social capital is generally studied in three dimensions based on the conceptual distinction that is useful for analytical convenience: structural, relational, and cognitive (Nahapiet and Ghoshal, 1998). Structural dimension is the dimension in which social systems such as groups and organizations are considered as a whole rather than as individual relationships. This dimension has components such as the connection patterns between actors, the structure of communication network, the presence and absence of these relationships, the degree to which the information to be obtained depends on individual and cultural values, and the hierarchy in the network (Ahuja, 2000; Uzzi, 1997 Nahapiet and Ghoshal, 1998;). On the other hand, the relational dimension of social capital refers to the sources of relationships such as trust, reliability, norms, obligations, and identification (Coleman, 1988; Putnam, 1993). Finally, the cognitive dimension of social capital refers to systems of representation, interpretation, vision, and meaning shared among the parties, including collective narratives with common language and vocabulary (García-Villaverde et al., 2018; Inkpen and Tsang, 2005; Nahapiet and Ghoshal, 1998; Tsai and Ghoshal, 1998; Uzzi, 1997).

This study focuses on the structural dimension of social capital, which consists of networks and relationships. The structural dimension of social capital shows the relationship among actors, who constantly share information. The actor who benefits from this information increases own ability to attract, analyze, and reconcile others. Therefore, structural social capital is seen as the key concept in management and 
organizational science (Nahapiet and Ghoshal, 1998). Structural social capital is explored at various levels between individuals and within social networks as a contextual factor that affects the objective nature of social behaviors. In particular, this issue garners intense interest from researchers by associating network relationships and ties with concepts such as organizational memberships, volunteering, social participation, citizenship activities, and many others (see DeSilva et al., 2007; Nyqvist et al., 2012; Agampodi et al., 2015).

Among the frequently encountered concepts in the organizational level studies about structural social capital regarding the concept of social network structure and position are network centrality, size, density, homogeneity/heterogeneity, homophilia/heterophilia, constraints, size, frequency, redundancy, along with the strength of network ties, both strong and weak, structural holes, social connections that involce such elements as network memberships, association memberships, and social participation, but also research that focuses on relationships involving bonding, bridging, and linking ties and connectivity (Acquaah et al., 2014). Researchers focus on discovering antecedents and effects of social capital in the management and organizational literature. Recently, many empirical and review studies appeared from the structural social capital perspective. These studies focus on different topics periodically. The focus of the studies made in the late 1990s and 2000s was transactions between organizations (Chung, Singh, and Lee, 2000; Tsai, 2000), resource allocation (Bouty, 2000), innovation diffusion (Tsai and Ghoshal, 1998), change management (Gargiulo and Benassi, 2000), project-based companies (DeFilippi and Arthur, 1998), and the impact of human and social capital on interdependence. The importance of social interactions and connections in the management and organizational science has continued to increase in the last decade as well (Rhee and Leonardi, 2017).

Bibliometrics - a well-established research method in information science - is considered an effective tool to examine the status of a research subject (Jia, Dai, and Guo, 2014). Therefore, this study offers a bibliometric analysis of the literature, which allows a regular, systematic, and quantitative evaluation of published articles to identify the underlying structure underlying this research area and the main research themes of the scholarship. We conducted a bibliometric analysis using international databases to explore the main concepts and themes of the management and organization literature and to identify its main themes. Based on our findings, we aimed to clarify the conceptual boundaries of the literature regarding the structural social capital features formed in the field of the management and organization so as to identify important gaps in our knowledge base and offer a roadmap for future research. The bibliographic matching technique was used to organize the studies on the structural social capital 
characteristics anchored in the reference works shared in the management and organization literature published from January 1, 2009, to December 31, 2020. Consequently, the research questions of this research were: How structural social capital may influence management and organization literature? What are the main themes in the management and organization literature in which structural social capital elements are explored or studied together? And, do there appear changes and trends in these main themes?

\section{Social Capital and Its Dimensions}

Social capital is a multidimensional concept studied by academicians with different perspectives from different disciplines such as sociology, anthropology, political sciences, economy, and organizational studies (Huggins and Johnston, 2010; Lehner, 2014). It has become a concept that encompasses different social areas of analysis such as interactions, relationships, bonds, trust relations, values, and systems of norms that facilitate the actions and activities of the individual in a specific context (Anderson and Jack, 2002, p. 193). In terms of social capital, social networks are used as a variable both in defining the concept and explaining how social capital is used to achieve desired results. Since the behaviours of actors embedded in networking mechanisms consist of their relationships (Granovetter, 1985), the theories that constitute the theoretical framework of social capital have developed based on social networks. Social networks are critical sources for the creation and development of social capital (Alan and Sozen, 2017). As actors in social networks increase the benefits obtained from their mutual relations and trust (Putnam, 1993, p. 171), we may say that the most important element of social capital is participation in social networks that result from social relations. Therefore, social relations are considered an important resource that actors gain, use, and accumulate.

Social capital is a concept that explores benefits and advantages of individuals, which are gathered through their membership in official institutions and non-governmental organizations through social relations and interactions (Nahapiet and Ghoshal, 1998). In another definition, social capital is defined as a resource created by actors through out-of-network connections and used in achieving their goals (Adler and Kwon, 2002). According to Tsai and Ghosal (1998, p. 464), social capital is a relational resource present in personal ties that is useful for the development of individuals in the social structuring of the society. On the other hand, Burt (2001, p. 32) defines social capital as the complement of human capital by stating that "those who do better are better interconnected in some way." Moreover, he evaluates social capital as a function of mediation possibilities 
that arise from the position in the structure and structural gaps. In terms of organizational studies, social capital can be defined as the resources gained from socioeconomic and cultural relations, which is examined as an element that can adapt or prevent patterns of social and cultural relations (Granovetter, 1985, pp. 481-510).

As we may see from the definitions, scientists' perspectives on social capital differ. The definitions related to the concept of social capital were classified into three groups by Adler and Kwon (2002). According to Sargut (2006, p. 4), the definitions in the first group focus on the relationships formed by the actors with other actors, while the definitions in the second category try to explain the structure of relations between actors in a community. Finally, the definitions that deal with relationships between actors and the structure of these relationships are included in the third category. From these definitions, we may say that what the concept of social capital comprises are relationships and networks among people, groups, and organizations, the social norms and values created by these relations, and the trust created by both the relations and the norms. Indeed, this situation presents three different dimensions of social capital. According to Nahapiet and Ghoshal (1998), the three-dimensional grouping based on structural, relational, and cognitive characteristics of social capital respectively corresponds to social interaction, trust relationships, and shared goals and culture. Structural social capital is an important dimension of social capital as it expresses the structural features of social relations (Lin, 1999) and focuses on the characteristics of the network of relationships as a whole (Nahapiet and Ghoshal, 1998, p. 244). Structural aspects of social capital can be measured by network size, source of social connections, member heterogeneity, number of contacts, and frequency of social participation, reciprocity, and multiplicity (Berkman and Glass, 2000; Ell, 1984). The structural dimension concerns the general pattern of connections in a social network. The subject of the structural dimension is the variety of actors in social networks in general. The important point of the structural dimension is that a social network defines the kind of social interaction that should be established to access a certain resource. Network connections provide access to the resources which constitute the basis of social capital. Therefore, the most important aspects of this dimension are the presence or absence of network ties and network configuration (Wasserman and Faust, 1994). The ties in a social network are the source of social interaction or social change, closely related to the flow of information and resources (Coleman, 1988). While these ties are important for communication, their formation is particularly important for social capital development (Nahapiet and Ghoshal, 1998).

The structural dimension represents opportunities to benefit from an actor's resources and without taking action nearby (Adler and Kwon, 2002). The structural dimension 
includes network components and aspects such as the existence of ties among actors, the configuration and density of a network such as hierarchy within an organization, structural gaps in networks, and network configuration and connectivity. From this perspective, the characteristics of structural social capital provide actors with access to unequally distributed information. Therefore, analyzing the network structure in structural social capital studies is considered important. As a result, we can say that the structure of social network relationships and the position of social actors in a network affects the actor's situation.

\section{Development of Structural Social Capital Studies in Management and Organization Science}

The issue of social capital is studied conceptually and empirically by scholars from different disciplines as an important variable in terms of management and organizations (i.e. Fukuyama, 1995; Nahapiet and Ghoshal, 1998). Indeed, whether based on an individual or an organization, the social capital has been a concept that examines and develops on the relationship of an actor with other actors. Therefore, the development of social capital studies can be considered to run in parallel with social network studies. In management and organizational science, what played an important role in focusing the attention of researchers on network relations was especially the embeddedness debate in the study by Granovetter (1985). Many researchers (Walker, Kogut, and Shan, 1997; Gulati, 1995, 1998; Gulati, Dialdin, and Wang, 2002; Stevenson and Greenberg, 2000) find that the basis of network research is understanding how the settlements of individuals affect behavior, and so they work on developing similar situations for organizations. In terms organizations, social capital can be defined as the resources gained from socioeconomic and cultural relations, and it can be examined as an element that adapts to all production stages of social and cultural relationship patterns (Granovetter, 1985, pp. 481-510).

The most prominent and emphasized dimension in social capital studies is the structural dimension that contributes to sharing information, joint actions and decision-making through established roles, social networks, and other social structures, supported by rules, procedures, and cases (Leana and Pil, 2006). Some of the well-known or most common components of structural social capital researches in the literature are Granovetter's (1985) weak ties, Putnam' (1995), Coleman’s (1988), and Bourdieu's (1983) strong ties, and Burt's (1980) structural holes and brokerage theories. Granovetter (1973) considers the strength of weak ties, while Burt (1992) reflects on the advantages of established relationships of organizations while explaining the concepts of structural 
holes in the network. What is certainly important in these studies are the contextual conditions on which the individual depends and the purposes of the network relationship. As a result, when considering social capital, we should deal with four different structural components of networks, namely network size, centrality, structural holes, and the strength of ties.

Scholars state that one of the most important advantages of social capital is to reach new sources of information (Inkpen and Tsang, 2005). However, there are different opinions about the kind of structure that actors in network mechanisms could benefit from by increasing their social capital. Gulati, Dialdin, and Wang (2002) posit that structural dimensions of the network mechanism in which an organization is located are the determinants of organizational benefit from network relations. Therefore, when considering a subject from the network perspective, we should consider the parameters related to structural dimensions. The literature often mentions that each sub-dimension of the structural dimension is addressed separately due to the lack of agreement and consensus on what kind of network structure is "best" for the management and organizations (Gargiulo and Benassi, 2000). While one view emphasizes that the existence of strong relations ensures positive results by providing trust and cooperation among actors, the other view foregrounds that social capital is linked to intermediation opportunities created by dispersed network relationships (Gargiulo and Benassi, 2000). These different views have brought along the open-closed structure debate that results from the concept of the strength of ties.

Granovetter (1973) supports the view that weak ties provide more information advantages than strong ties by arguing that weak ties are more important in the dissemination of knowledge and resources since such ties can serve as bridges among social groups that typically are separated from each other. According to him, social network ties - also referred to as tie strength - represent a bipolar continuity in which one end represents weak relationships and the other represents strong relationships (Perry-Smith and Shalley, 2003). The movement in this continuity depends on the frequency of interaction between two individuals, reciprocity, emotional intensity, and proximity to social interaction (Granovetter, 1973).

Burt (1992) argues that not only the size of the network but also the diversity of network connections is important. He mentions the importance of bridging the gaps between separated social actors, which he calls structural holes. According to Burt's (1992) structural hole theory, bridging these gaps by bonding the relations that connect different social actors is the most advantageous position. He also states that social capital emerged as a result of intermediary formations in social networks. In other words, Burt (1992) 
emphasizes the superiority of social capital acquisition with the knowledge and control power gained by organizations that are not familiar with each other in a social structure, organization communities and individuals. Indeed, these structural dimensions mentioned in the theoretical foundations are interrelated. Accordingly, Burt (1992) strongly supports Granovetter's (1973) seminal study on weak ties, which argues that the benefit of social capital stems from structural holes.

The structure of ties in networks is another important issue addressed in terms of innovation management, due to its role as a channel of knowledge that enables information exchange among organizations (Powell, Koput and Smith-Doerr, 1996; Ahuja, 2000). Considering innovation literature, we may see that some factors such as information access and sharing, information flow, resource change, and complementarities as the driving forces of innovation in both scarce and intensive network configurations (see Ahuja 2000; Alguezaui and Filieri, 2010). In his effective work on the structural dimension of social capital on innovation, Ahuja (2000) found that direct ties, indirect ties and structural holes play different roles in acquiring new knowledge, resources, and various information to achieve innovations. Regarding the innovation providers of structural dimension, scholars suggest that network configuration or structure can increase information efficiency (Ehlen et al., 2014). Positional advantage and reputation can facilitate access to venture capital investments when an alliance needs to innovate (Partanen et al., 2008). Regarding innovation barriers reduction, some argue that finding an adequate network configuration or structure helps to reduce collaboration challenges and the risk of mismatched capabilities within a network.

As we may see, the social capital is a very important, informal value that increases cooperation and solidarity between individuals and organizations in society. Due to its wide influence on the power of understanding and measurement in studies, the concept of social capital is widely used in the literature as a social analytics tool for explaining the achievements of organizations.

\section{Material and Methods}

\section{Research Methodology}

Bibliometric analysis is one of the most appropriate approaches used to examine the evolution of research areas on issues based on social, intellectual, and conceptual structures of disciplines (Donthu, Kumar, and Pattnaik, 2020). To implement that approach, we analyzed publications records from 2009 to 2020 on Thomson Reuters' Web of Science database, which holds the largest and most preferred database of 
academic texts in the world. By using the bibliometric approach, we indexed all journals from these records in either Science or Social Science Citation Index, highlighting the focused and bridging research themes of 2383 articles written on the "structural social capital" characteristics. Parallel to the research objectives, we adopted the keywords co-occurrence network, which is used in co-word analysis, one of the main methods of bibliometrics (Zupic and Cater, 2015).

For the visualization of bibliometric networks, we utilized KH Coder text mining software (Ver. 3. Alpha. 9). To address the research questions, we employed a list of keywords in titles from the management and organizational studies category. We determined three main themes regarding the content of structural social capital. These main themes consist of structural and positional variations of ties, network structure, and the diversity of network configuration. The searched keywords included "network size," "strong ties," "strength of ties," "tie strength," "weak ties," "structural holes," "brokerage," "bridging ties," "bonding ties," "linking ties," "network closure," "network position," "density," and "centrality" under the topic of structural social capital. Table 1 shows the main themes and related keywords. These keywords cover the basic concepts, features and elements of structural social capital in general. The keywords were searched according to the "all field" category of the current database. For this reason, around 2383 articles were found just in the Web of Science database by searching whether they include the keywords arranged above in "title," "abstracts," and "keywords" article categories. The collected data were saved in .xls and .doc formats. Keywords referring to the same concept are gathered in a standardized word. Duplicates and all synonyms were removed. Various forms of the same words are merged. Words with low frequency were modified to a similar word if there is a similar word in keywords. Words were removed if there was no similar word for the rare words. Moreover, the words that were too common or general were ignored.

Our study sought to identify research and articles in management and organizational science literature that focuses on structural social capital over the years and to reveal the changes and trends in the focus of these articles. To reveal the periodic focus differences in the studies, the data from the Web of Science database were obtained at four-year intervals. In total, three basic periods were framed. This bibliometric research brought many new and different perspectives. First, the study applied the scientific mapping approach to the emerging field of structural social capital and management organization in order to minimize subjectivity and bias. Second, in-depth analysis of identified research themes expanded the mapping approach. Third, the study analyzed research topics, identified important gaps, and provided future pathways by uncovering issues mostly associated with issues related to structural social 
capital in management, organization, and business literature. The research design is presented in Figure 1 to clearly show the research methodology.

Figure 1. Research Design for the Bibliometric Study

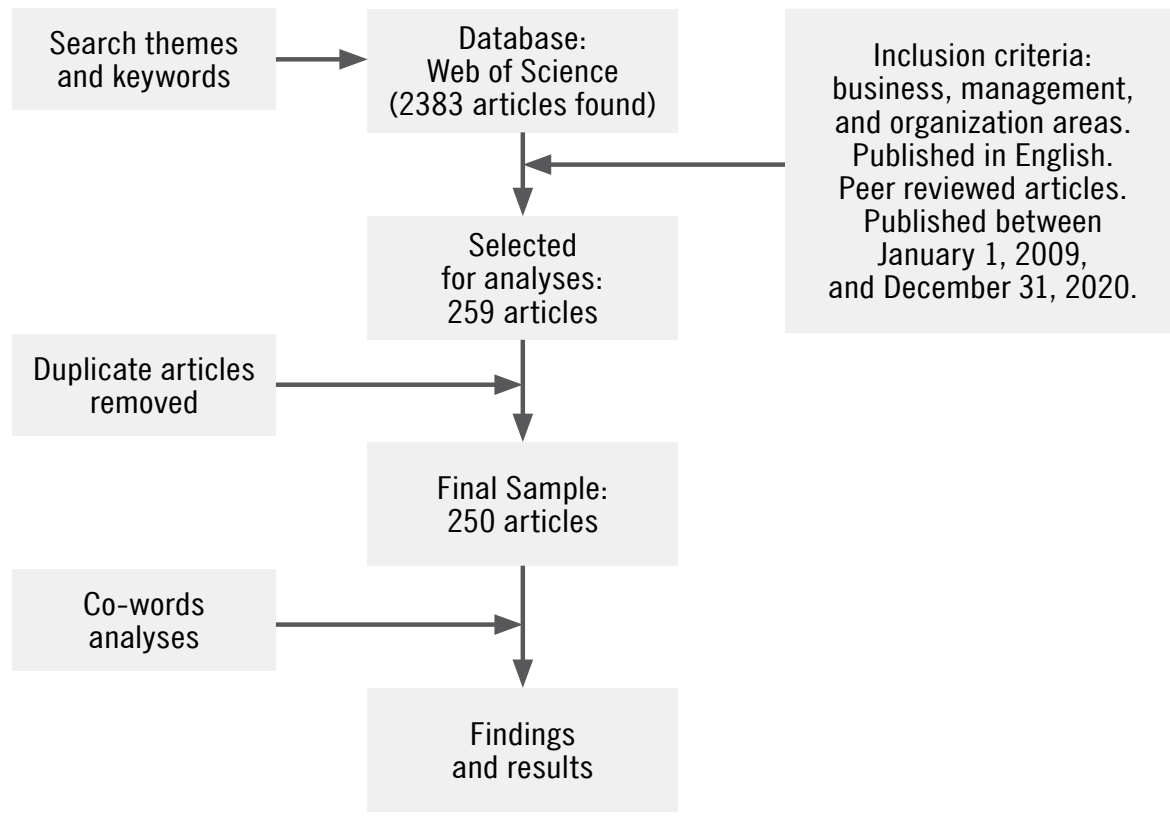

Source: own elaboration.

\section{Bibliometric Analysis}

The maps used in bibliometrics help to identify the main concepts or research themes of the interested area (Cobo et al., 2011).

Co-word analysis was the most preferred because it investigated the relationships amongst all words found together in keywords, abstracts and publication titles (Zupic and Cater, 2015). This study used co-word analysis to discover the main research themes in "structural social capital" literature. We specialized in the field of social capital and social network verified the research themes. Next, we conducted co-occurrence, term extract, term frequency, and clustering analysis on article records that belong to the three four-year terms under scrutiny by using the KH Coder text mining software. The frequency of each research term was counted through the KH Coder text mining program, and the relationships between tagged parses were calculated 
using the Jaccard indices. The Jaccard index is calculated as shown in equation (1), in which $J, x$, and $y$ represent the decompositions of the respective subjects. $J$ indicates the degree to which words appear together:

$$
J(x, y)=|x \cap y| /|x \mathrm{U} y|
$$

Cluster analysis is another popular technique that uses data analysis algorithms. Clustering in a text mining context helps to better understand themes, concepts, or events by dividing a collection of documents into groups based on the presence of similar themes (Goutam, Murali, and Statish, 2013). Table 1 shows the main themes and related keywords that we created inspired by the studied literature.

Table 1. Years, themes, sub-themes, keywords, and the number of articles related to structural social capital

\begin{tabular}{|c|c|c|c|}
\hline Periods & Themes & Keywords & N (articles) \\
\hline \multirow{3}{*}{ 2017-2020 } & $\begin{array}{l}\text { Structural and } \\
\text { Positional Variations of } \\
\text { Ties }\end{array}$ & $\begin{array}{l}\text { Strong Ties } \\
\text { Strength of Ties } \\
\text { Tie Strength } \\
\text { Weak Ties } \\
\text { Structural Holes } \\
\text { Brokerage }\end{array}$ & 509 \\
\hline & Network Structure & $\begin{array}{l}\text { Network Size } \\
\text { Network Closure } \\
\text { Density } \\
\text { Centrality }\end{array}$ & 569 \\
\hline & $\begin{array}{l}\text { Diversity of Network } \\
\text { Configurations }\end{array}$ & $\begin{array}{l}\text { Bridging Ties } \\
\text { Bonding Ties } \\
\text { Linking Ties }\end{array}$ & 226 \\
\hline \multirow{3}{*}{ 2013-2016 } & $\begin{array}{l}\text { Structural and } \\
\text { Positional Variations } \\
\text { of Ties }\end{array}$ & $\begin{array}{l}\text { Strong Ties } \\
\text { Strength of Ties } \\
\text { Tie Strength } \\
\text { Weak Ties } \\
\text { Structural Holes } \\
\text { Brokerage }\end{array}$ & 319 \\
\hline & Network Structure & $\begin{array}{l}\text { Network Size } \\
\text { Network Closure } \\
\text { Density } \\
\text { Centrality }\end{array}$ & 273 \\
\hline & $\begin{array}{l}\text { Diversity of Network } \\
\text { Configuration }\end{array}$ & $\begin{array}{l}\text { Bridging Ties } \\
\text { Bonding Ties } \\
\text { Linking Ties }\end{array}$ & 185 \\
\hline
\end{tabular}




\begin{tabular}{|l|l|l|}
\hline Structural and & $\begin{array}{l}\text { Strong Ties } \\
\text { Strength of Ties } \\
\text { Positional Variations } \\
\text { of Ties }\end{array}$ & $\begin{array}{l}\text { Tie Strength } \\
\text { Weak Ties } \\
\text { Structural Holes } \\
\text { Brokerage }\end{array}$ \\
\hline $\mathbf{2 0 1 2 - 2 0 0 9}$ & $\begin{array}{l}\text { Network Size } \\
\text { Network Closure } \\
\text { Density } \\
\text { Centrality }\end{array}$ \\
\hline Network Structure & $\begin{array}{l}\text { Bridging Ties } \\
\text { Bonding Ties } \\
\text { Linking Ties }\end{array}$ \\
\hline Diversity of Network \\
\hline Configuration
\end{tabular}

Source: own elaboration.

All computations and visualizations were performed with the KH Coder program (Ver. 3. Alpha. 9). At the first stage, we gathered the list of all keywords and words in titles and abstracts. Our attention was restricted to the words from more than 250 publications. This bibliometric analysis included trend analysis, cluster analysis, and word frequency (co-word) analysis. Trend analysis is required to identify the main trends and changes in structural social capital publications. The number of publications was determined by considering the most popular journals by year of publication, in management and organization, and by countries with the highest number of publications. The differences between the articles of the three four-year terms shed light on the subject of trends and changes.

For trend and change analysis, main themes should be selected from the data set. Thus, we first gathered article titles, keywords, and abstracts that belonged to the three four-year periods under scrutiny. The total number of sentences for each period was determined through the data analysis program. The words and sentences found meaningless and unrelated to the subject were removed from the data sets. The number of sentences removed and the number of sentences included in the analysis are shown in Table 2. 
Table 2. The list of eliminated and researched sentences according to research periods

\begin{tabular}{|r|c|c|c|}
\hline Period & $\begin{array}{c}\text { Total items } \\
\text { (sentence) }\end{array}$ & $\begin{array}{c}\text { Deleted items number } \\
\text { (sentence) }\end{array}$ & $\begin{array}{c}\text { Final sample } \\
\text { (sentence) }\end{array}$ \\
\hline $2009-2012$ & 468 & 250 & 218 \\
\hline $2013-2016$ & 592 & 372 & 220 \\
\hline $2017-2020$ & 528 & 295 & 297 \\
\hline
\end{tabular}

Source: own elaboration.

Considering the number of sentences included in the analysis, as presented in Table 2, the largest data set belongs to the third period. Data sets differ between periods. The reason for this is that the studies in the field of management, organization, and business related to structural social capital appeared in different numbers each period. Moreover, Table 1 shows that most articles belong to the third period. First, the bibliometric analysis was started with correspondence analysis, which is suitable for exploring the relationships between the most repeated qualitative variables or categorical data that belonging to the data sets divided into periods. Like principal component analysis, the above analysis summarizes and visualizes the data set in two-dimensional graphs (Kroonenberg and Greenacre, 2005). At the same time, correspondence analysis categorically allows for the investigation of missing data and provides an alternative method for plotting trend data as a movement between points in a multidimensional space (Kroonenberg and Greenacre, 2005, p. 35). In the correspondence analysis, similarities and differences are made meaningful not only between the levels specified in the rows of the data matrices or between the specified levels. The fact that there are many studies on categorical data analysis makes the subject of correspondence analysis very attractive. It is a very popular method, especially in areas in which categorical data analysis is most needed such as medicine, health sciences, biometrics, economics, marketing, and social sciences (Greenacre, 1994). Following correspondence analysis, we show the most prominent themes for each period in Figures 1, 2 and 3. 


\section{Figure 2. Correspondence Analysis for 2009-2012 (Period I)}

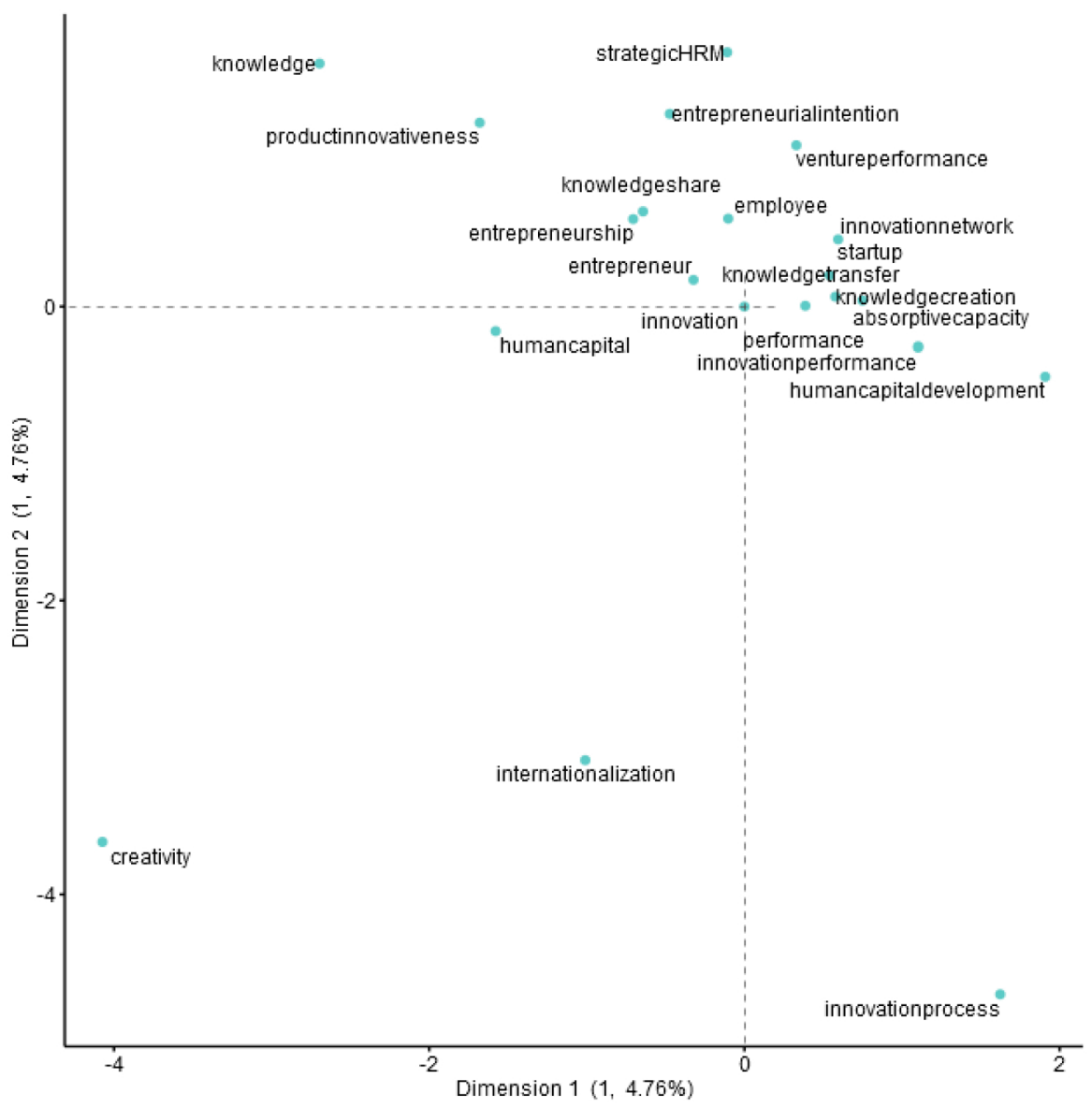

Source: own elaboration.

In Figures 2 and 3 appeared the most studied and researched concepts in the field of management and organization, which include structural social capital issues. When these concepts were examined, there formed different concept clusters belonging to the periods. 
Figure 3. Correspondence Analysis for 2013-2016 (Period II)

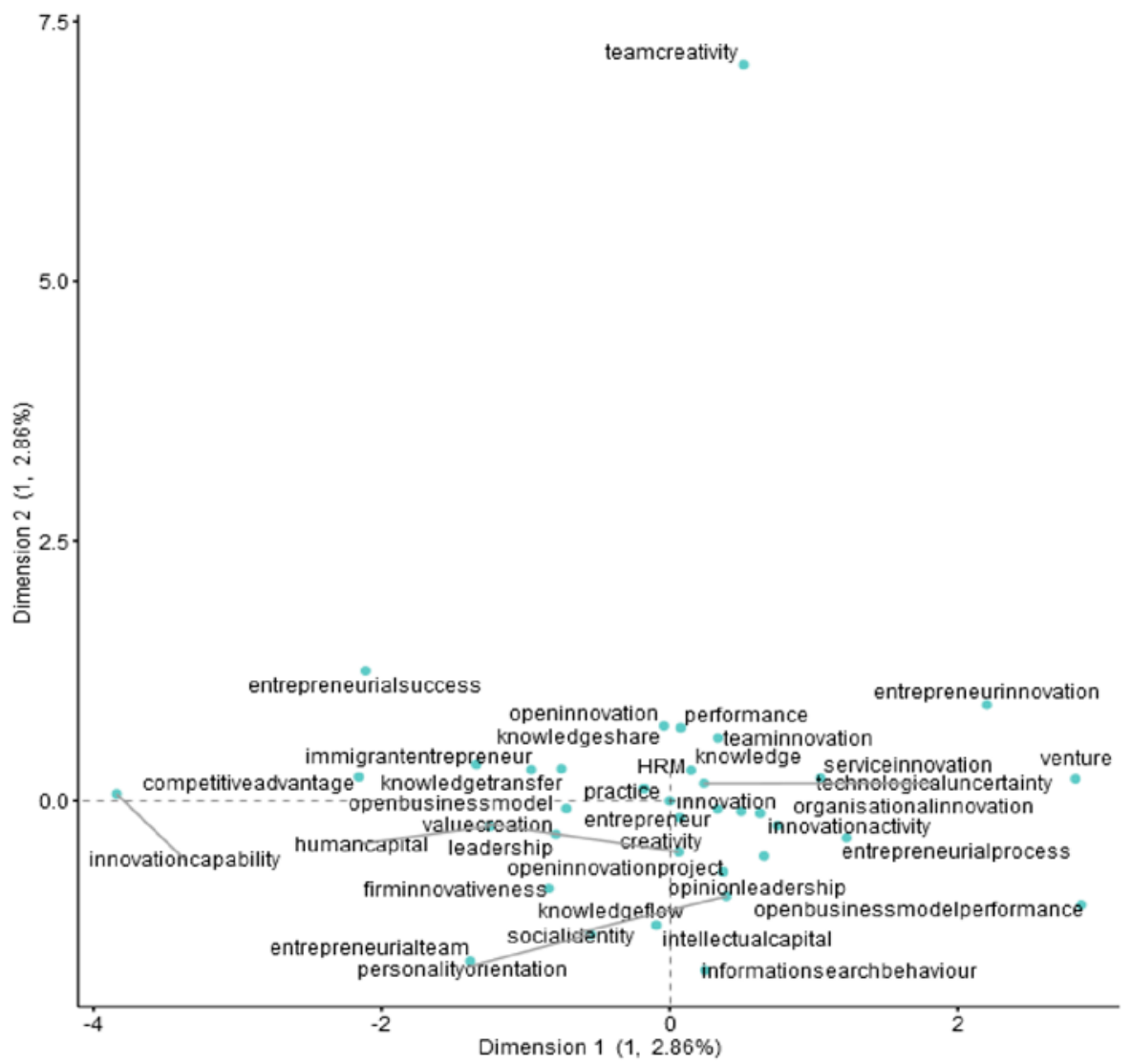

Source: own elaboration.

Figure 4 shows the themes that emerged in the most recent years. Such a visualization allows us to interpret all variables in the same space. Thus, it takes less time to reveal the structures and patterns with which the data is related. This analysis offers useful and practical solutions for researchers in the social sciences. Multiple categorical variables are evaluated simultaneously, helping us to show not only that there is a relationship but also how the variables are related. Thus, appropriate data can be collected quickly and easily from research (Hoffman and Franke, 1986). The graphical representations in Figures 2, 3 and 4 were formed based on the prominence of the most common words in the data sets. Accordingly, the list of the most recurring themes from each period are shown in Table 3 in detail. 
Figure 4. Correspondence Analysis for 2017-2020 (Period III)

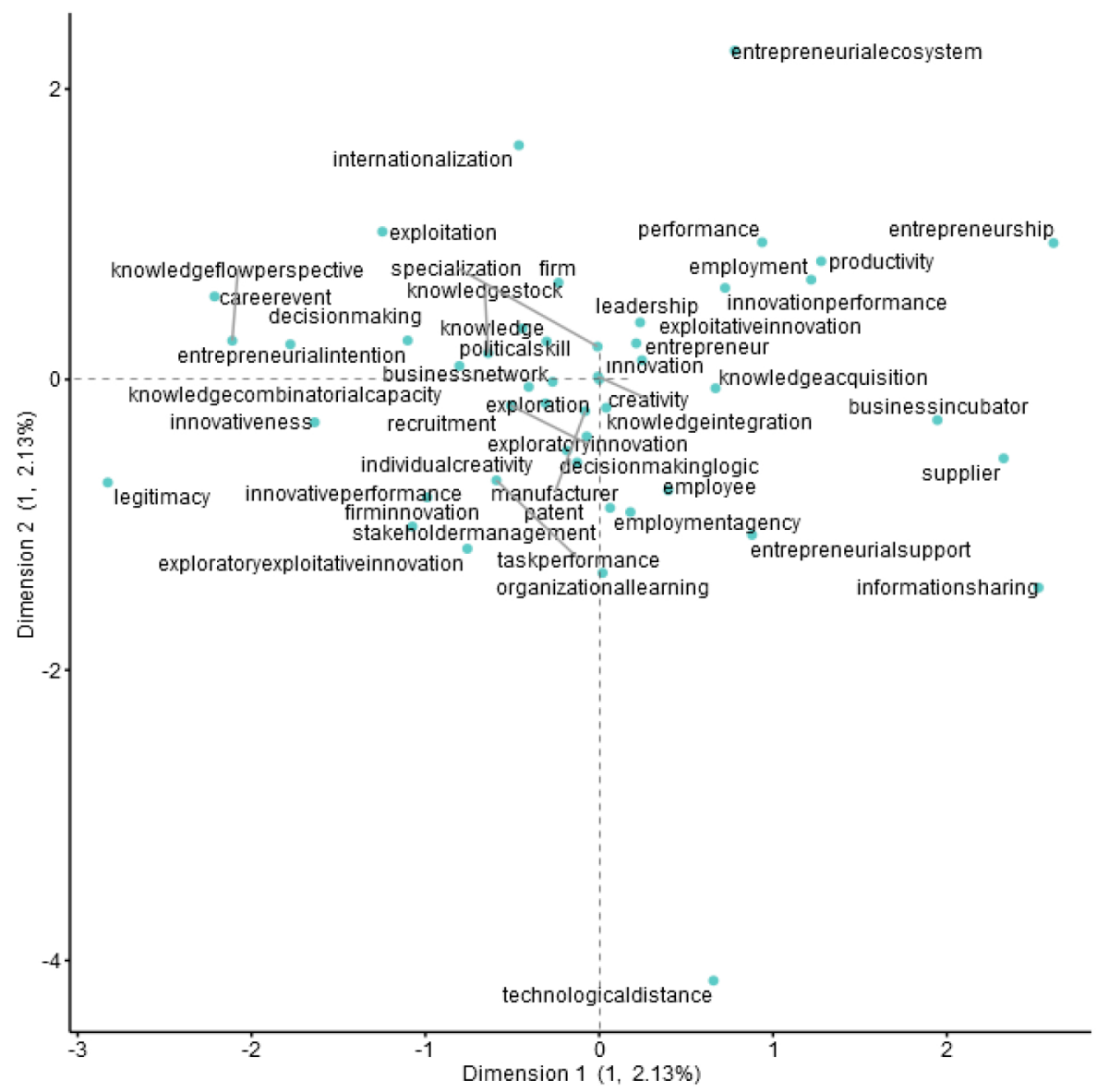

Source: own elaboration.

Table 3. The list of the top 30 most frequently seen themes by period intervals

\begin{tabular}{|c|c|c|c|c|c|c|}
\hline & Period I (2009-2012) & Df & Period II (2013-2016) & Df & Period III (2017-2020) & Df \\
\hline 1. & Innovation & 44.00 & Innovation & 17.00 & Innovation & 16.00 \\
\hline 2. & $\begin{array}{l}\text { Innovation } \\
\text { Performance }\end{array}$ & 17.00 & Entrepreneur & 15.00 & Entrepreneur & 12.00 \\
\hline 3. & Performance & 16.00 & Performance & 8.00 & Knowledge Integration & 11.00 \\
\hline 4. & Entrepreneur & 11.00 & Creativity & 6.00 & Internationalization & 10.00 \\
\hline 5. & Knowledge Creation & 9.00 & Leadership & 6.00 & Knowledge & 10.00 \\
\hline 6. & Entrepreneurship & 8.00 & Intellectual Capital & 5.00 & Performance & 10.00 \\
\hline 7. & Knowledge Transfer & 7.00 & Knowledge & 5.00 & Exploration & 9.00 \\
\hline
\end{tabular}




\begin{tabular}{|c|c|c|c|c|c|c|}
\hline 8. & Innovation Network & 5.00 & Knowledge Transfer & 5.00 & Exploitative Innovation & 6.00 \\
\hline 9. & Knowledge & 5.00 & Open Business Model & 5.00 & Exploratory Innovation & 6.00 \\
\hline & $\begin{array}{l}\text { Entrepreneurial } \\
\text { Intention }\end{array}$ & 4.00 & $\begin{array}{l}\text { Open innovation } \\
\text { Project }\end{array}$ & 5.00 & $\begin{array}{l}\text { Organizational } \\
\text { Learning }\end{array}$ & 6.00 \\
\hline & $\begin{array}{l}\text { Product } \\
\text { Innovativeness }\end{array}$ & 4.00 & Innovation Activity & 4.00 & $\begin{array}{l}\text { Entrepreneurial } \\
\text { Ecosystem }\end{array}$ & 5.00 \\
\hline & Creativity & 3.00 & Opinion Leadership & 4.00 & Legitimacy & 5.00 \\
\hline & Internationalization & 3.00 & Human Capital & 4.00 & $\begin{array}{l}\text { Technological } \\
\text { Distance }\end{array}$ & 5.00 \\
\hline & Absorptive Capacity & 2.00 & $\begin{array}{l}\text { Entrepreneurial } \\
\text { Process }\end{array}$ & 3.00 & Decision Making Logic & 4.00 \\
\hline & Employee & 2.00 & $\begin{array}{l}\text { Open Business Model } \\
\text { Performance }\end{array}$ & 3.00 & $\begin{array}{l}\text { Entrepreneurial } \\
\text { Intention }\end{array}$ & 4.00 \\
\hline & $\begin{array}{l}\text { Human Capital } \\
\text { Development }\end{array}$ & 2.00 & $\begin{array}{l}\text { Organisational } \\
\text { Innovation }\end{array}$ & 3.00 & Entrepreneurship & 4.00 \\
\hline & Innovation Process & 2.00 & Practice & 3.00 & Exploitation & 4.00 \\
\hline 8 & Start-Up & 2.00 & Service Innovation & 3.00 & $\begin{array}{l}\text { Innovation } \\
\text { Performance }\end{array}$ & 4.00 \\
\hline & Venture Performance & 2.00 & Competitive Advantage & 2.00 & Supplier & 4.00 \\
\hline & Acquisition & 1.00 & $\begin{array}{l}\text { Entrepreneurial } \\
\text { Success }\end{array}$ & 2.00 & Business Network & 3.00 \\
\hline & $\begin{array}{l}\text { High Technology } \\
\text { Venture }\end{array}$ & 1.00 & Entrepreneurial Team & 2.00 & Creativity & 3.00 \\
\hline & Capital & 1.00 & $\begin{array}{l}\text { Entrepreneur } \\
\text { Innovation }\end{array}$ & 2.00 & Employment & 3.00 \\
\hline & $\begin{array}{l}\text { Entrepreneurial } \\
\text { Resource Acquisition }\end{array}$ & 1.00 & Firm Innovativeness & 2.00 & Individual Creativity & 3.00 \\
\hline & Career & 1.00 & $\begin{array}{l}\text { Immigrant } \\
\text { Entrepreneur }\end{array}$ & 2.00 & Information Sharing & 3.00 \\
\hline & Clustered Firm & 1.00 & $\begin{array}{l}\text { Information Search } \\
\text { Behaviour }\end{array}$ & 2.00 & Leadership & 3.00 \\
\hline & Configuration Theory & 1.00 & Innovation Capability & 2.00 & Recruitment & 3.00 \\
\hline 27. & $\begin{array}{l}\text { Corporate } \\
\text { Performance }\end{array}$ & 1.00 & Knowledge Flow & 2.00 & Business in Cubator & 2.00 \\
\hline & Culture & 1.00 & Open Innovation & 2.00 & Career Event & 2.00 \\
\hline & Employment & 1.00 & Personality Orientation & 2.00 & Decision Making & 2.00 \\
\hline & $\begin{array}{l}\text { Entrepreneurial } \\
\text { Activity }\end{array}$ & 1.00 & Social Identity & 2.00 & Employee & 2.00 \\
\hline
\end{tabular}

Source: own elaboration. 
Keywords in Table 3 were sorted in descending order. We may say that the concepts in the list belong to the terminology of management and organization literature, and there are differences between these concepts depending on the period. In order to reveal the most basic research topics of management and organizational literature, cluster analysis is used to determine the most distinctive clusters of each period. The cluster analysis visualization of the periods is shown in Figures 5, 6, and 7.

Figure 5. The visualization of cluster analyses for Period I

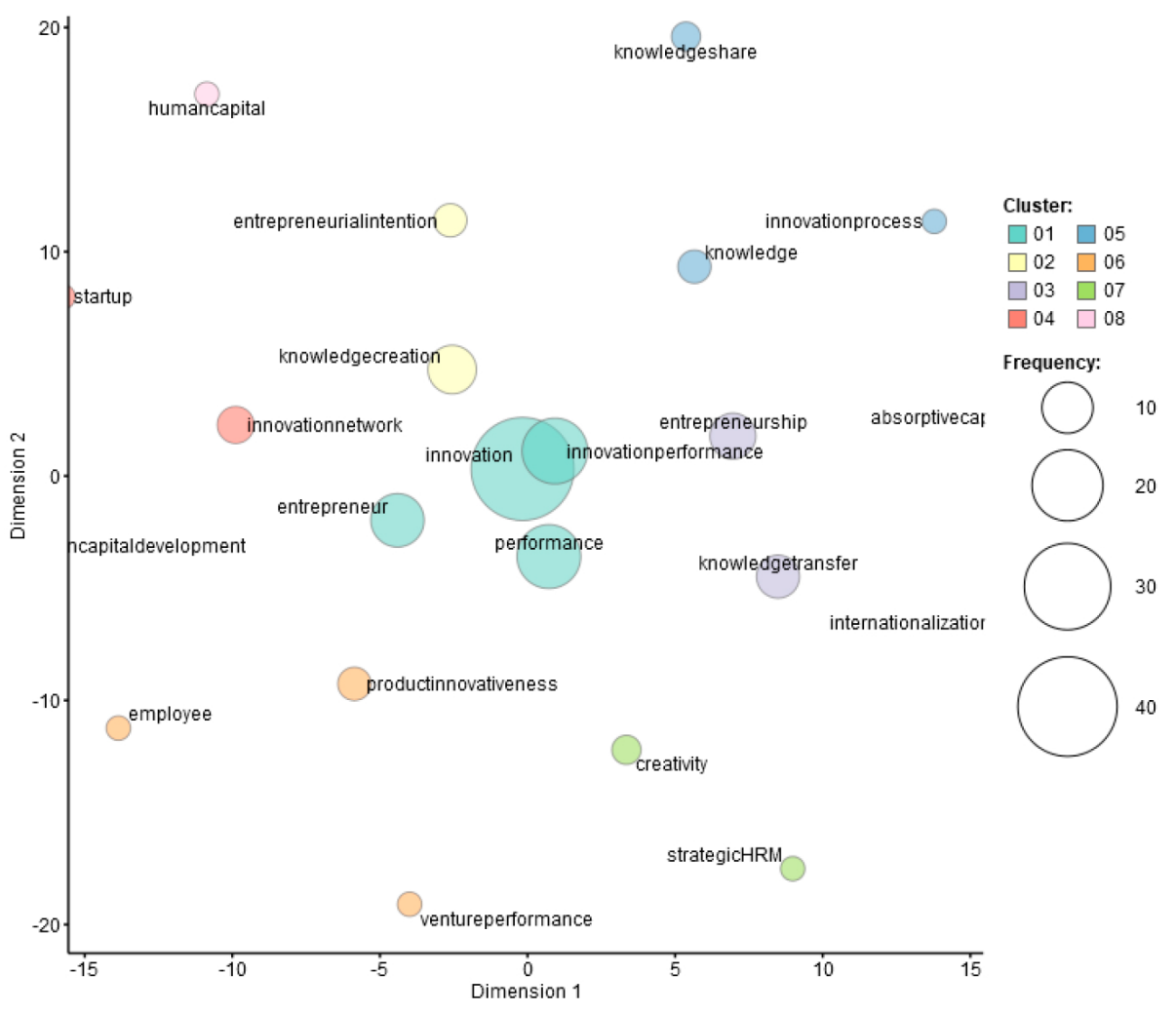

Source: own elaboration. 
Figure 6. The visualization of cluster analyses for Period II

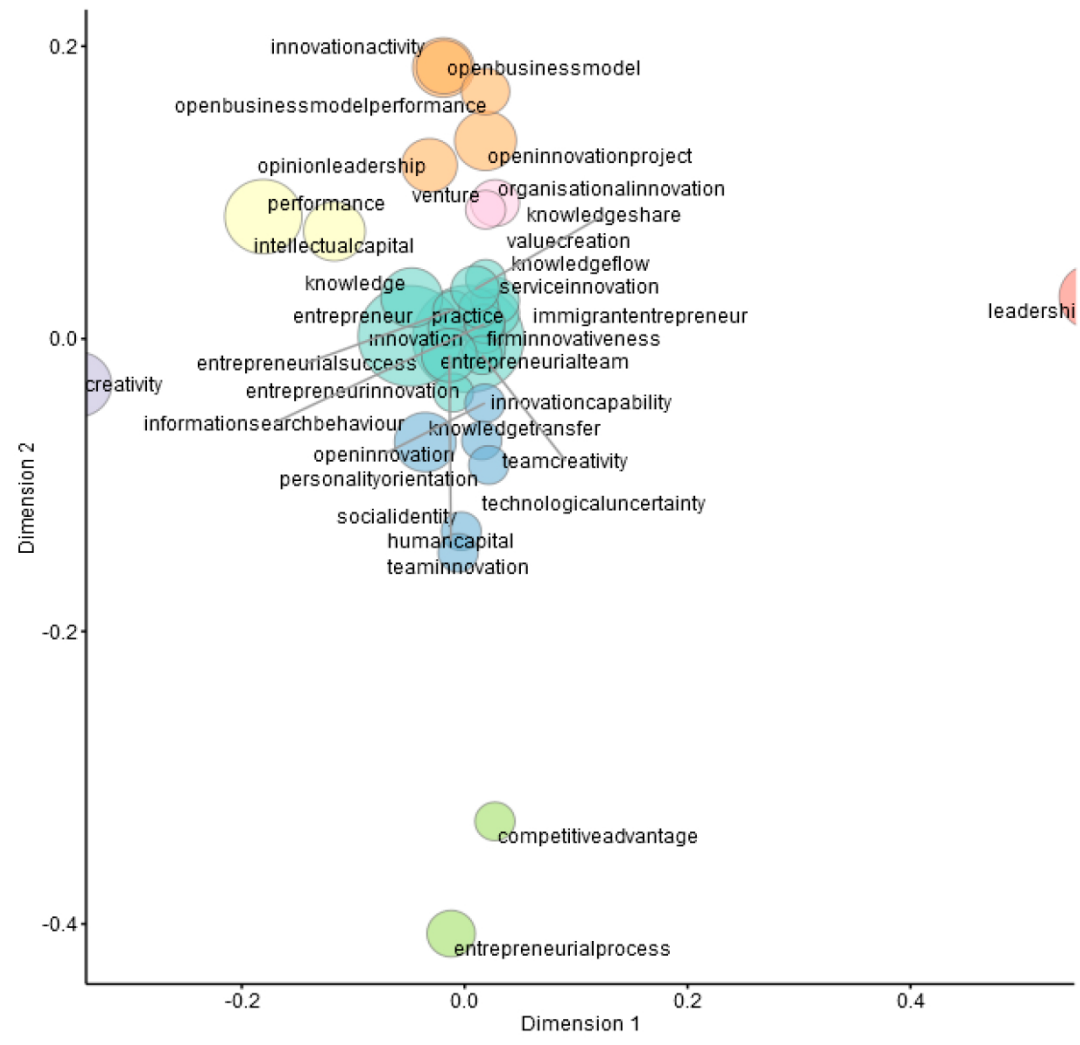

Source: own elaboration.

Following the cluster analysis, the descriptive and distinctive features of the articles belonging to each period were shown separately in Figures 5, 6, and 7. We may see that the data sets belonging to each period gather in eight clusters. In management and organization literature, cluster analysis is used as the basis for obtaining the semantic relationships of related subjects. Themes are represented by circles on the cluster visualization map for each period. The larger the circle, the heavier the theme. Themes in different sets have different colours. Lines between themes represent connections. If the lines are thick, it means strong connections between themes (Li et al., 2015). Accordingly, we see in Figure 5 that the words with the highest weight belonging to the first period (2009-2012) are "innovation," "innovation performance" and "entrepreneur," while in Figure 6 these are "innovation," "entrepreneurship success," "service oriented innovation." We may say that expressions are collected in eight clusters from high to low in Figures 5 and 6, while expressions belonging to different subjects gathered in clusters in Figure 7: "innovation," "performance," "entrepreneur- 
ship," "entrepreneurship," "knowledge production," and "knowledge sharing.” Their expressions seems to have too much weight, meaning that they may have a potential relationship by being featured in too many articles at the same time. If these two terms appear frequently again in the same article, at the same time, they are perceived as closely related.

\section{Figure 7. The visualization of cluster analyses for Period III}

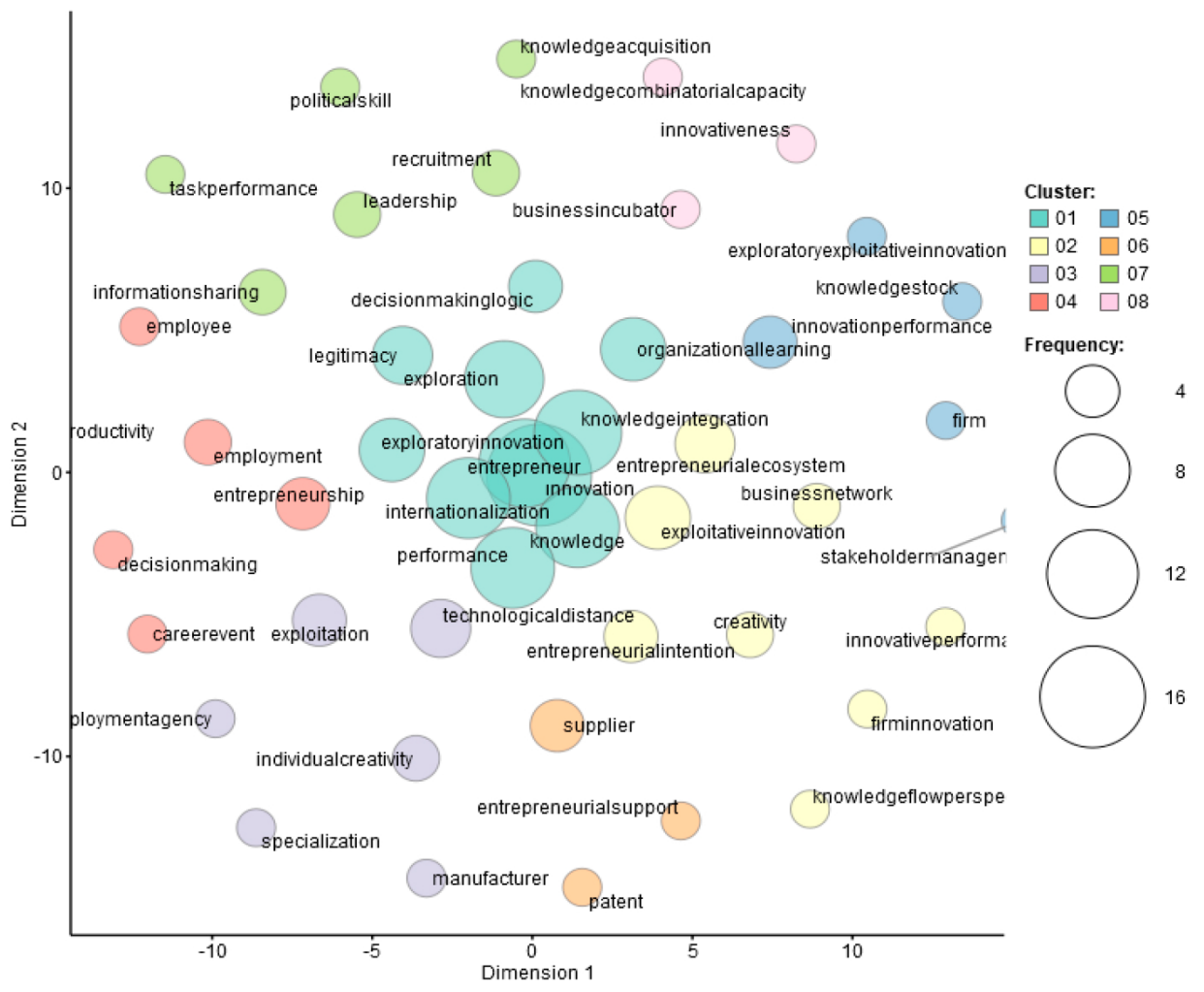

Source: own elaboration. 
Figure 8. Multidimensional correspondence analysis of co-words for all data set

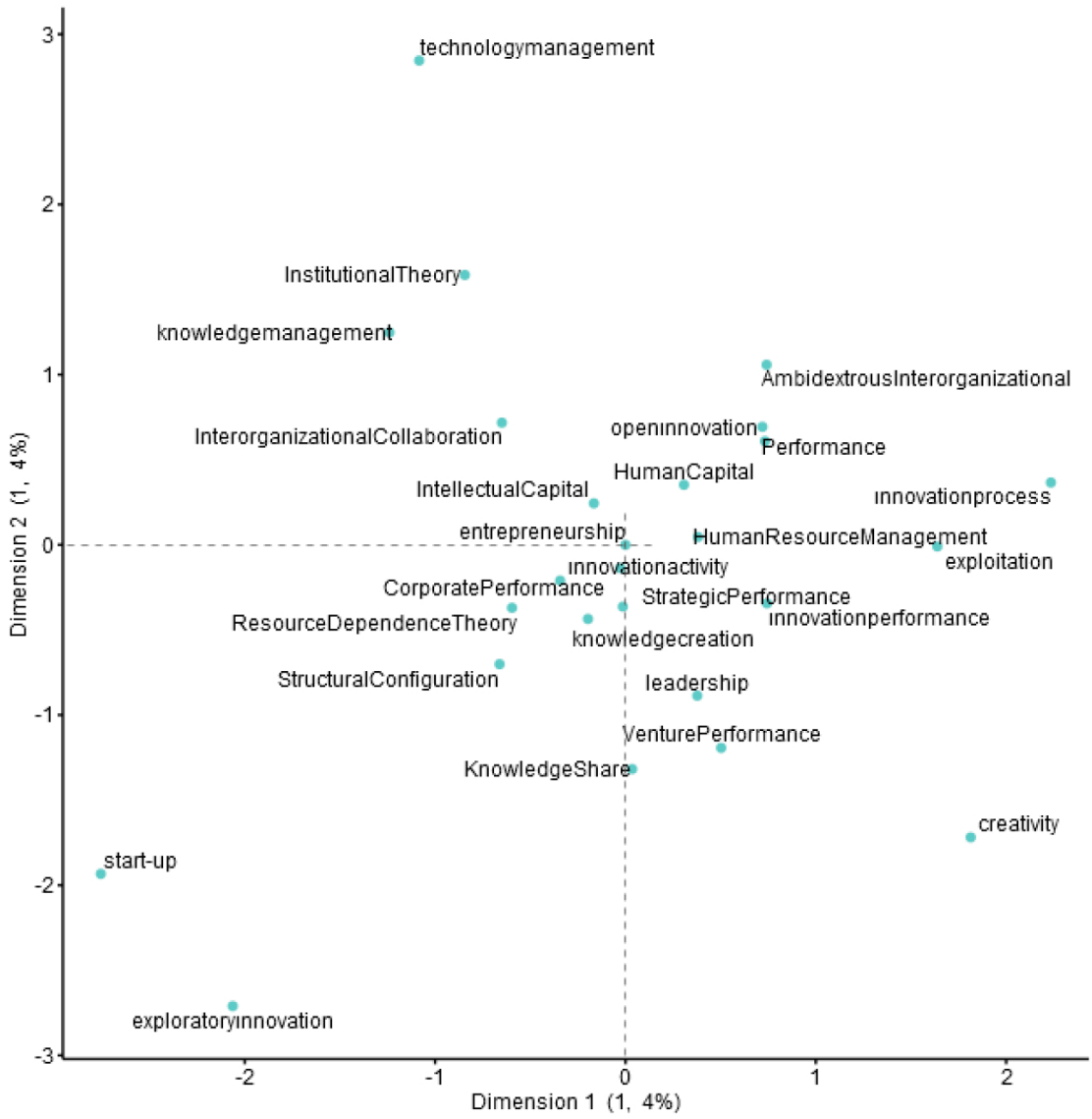

Source: own elaboration.

Figure 8 shows common words belonging to all data sets through a multidimensional analysis. 
Figure 9. Network visualization map of co-words for all data set
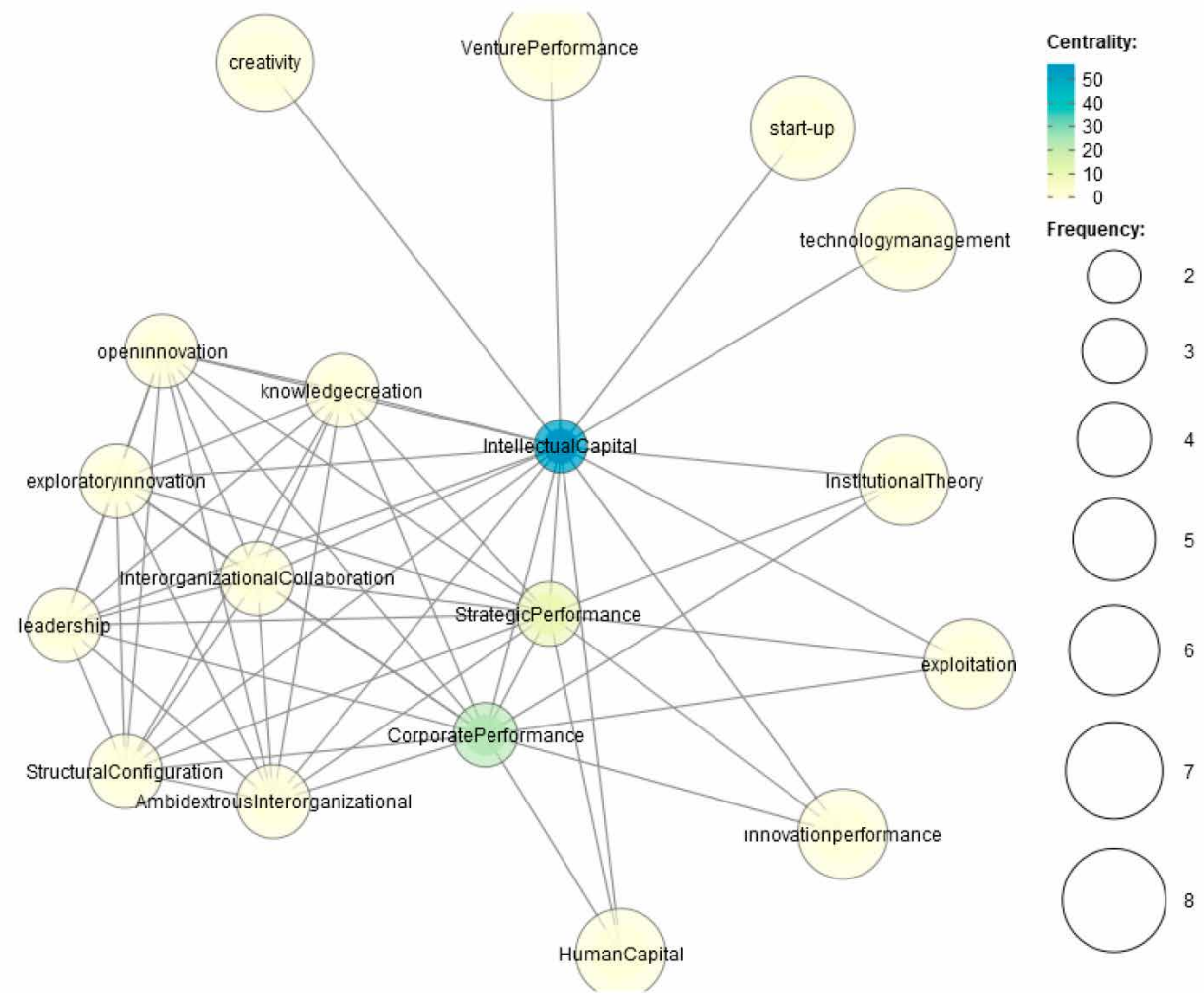

Source: own elaboration.

In Figure 9, items are represented by circles on the network visualization map. The larger the circle, the more weight has the item. However, the label may not appear for some duplicate items. Items in different sets have different colors. Lines between items represent connections. Figure 9 shows that the words with the largest circle representing the most weighted theme in the whole data set are those associated with the concepts of creativity, start-up, technology management, human capital, and venture capital. When we look at the centrality of the themes and the connections between them, the element with the most central position is intellectual capital. Likewise, the themes that are used jointly or by relation to each other are the concepts of inter-organizational cooperation, knowledge sharing, exploratory innovation, open innovation, structural configuration, leadership, and strategic performance. Determining the centrality and weight concepts of the elements associated with the keywords of structural social capital alone does not suffice to show the breadth or excess of the study and research area of these fields. Therefore, we prepared Figure 10, which presents 
the honeycomb visualization of the most reduced concepts with the network-based dimensionality reduction algorithm.

Figure 10. The visualizations of major topics in management and organization field for all data set

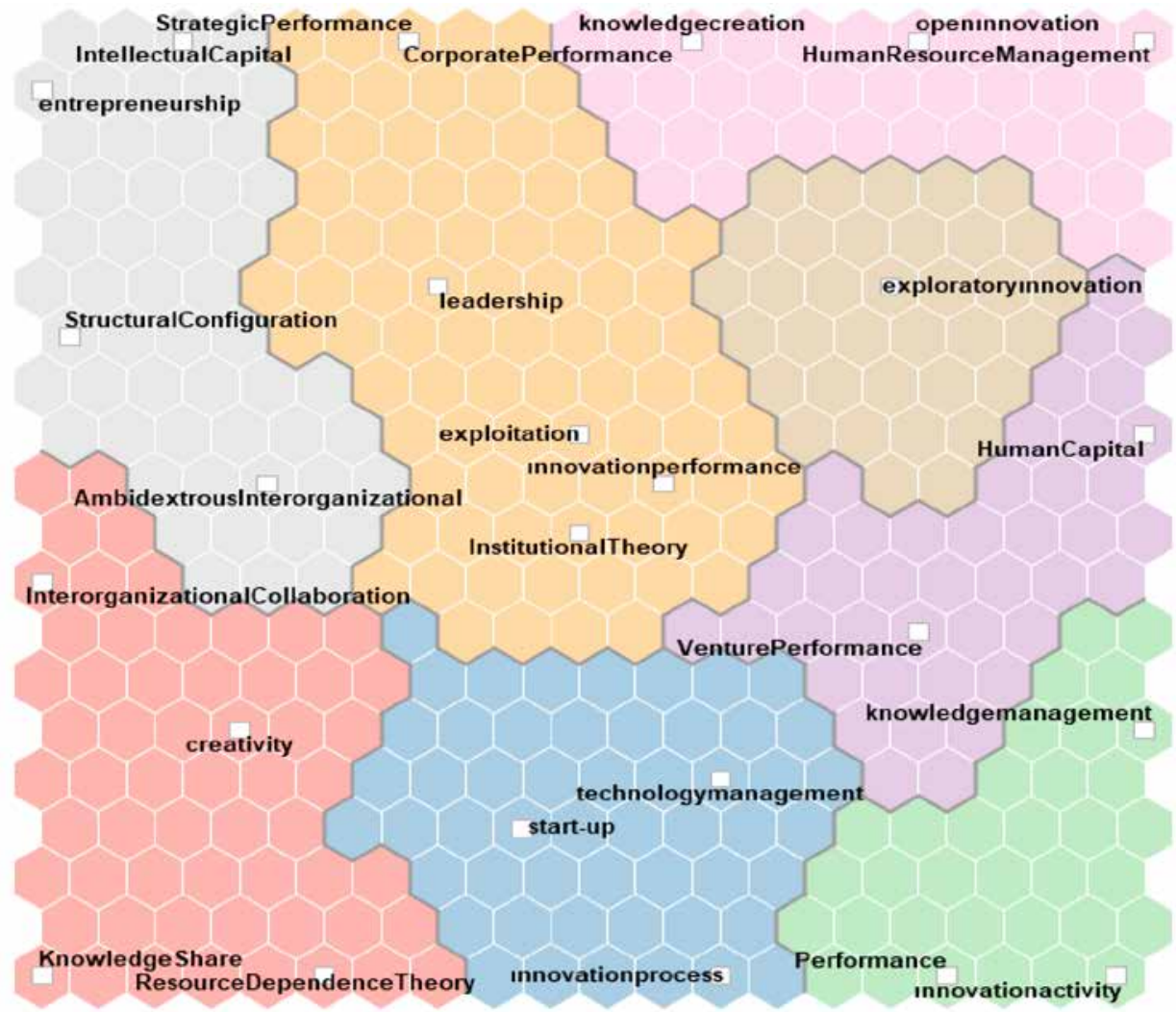

Source: own elaboration.

The self-organizing map is often a visualization of a network-based dimension reduction algorithm used to represent a high-dimensional data set as a two-dimensional discrete model. In Figure 10, each honeycomb area represents the occurrence frequency of all data sets. Thus, we notice that hot notions in management and organization leadership focus on the notions of "innovation performance," "corporate performance," and "corporate theory." Moreover, there are close links among these keywords. The list of the most matching common words is shown in Table 4. 
Table 4. The list of top 30 most viewed themes for all data set

\begin{tabular}{|c|c|c|c|c|c|}
\hline No & 2009-2020 & Frequency & No & & Frequency \\
\hline 1. & Entrepreneurship & 40.00 & 16. & Exploitation & 5.00 \\
\hline 2. & Human Resource Management & 19.00 & 17. & Knowledge Creation & 4.00 \\
\hline 3. & Innovation Activity & 17.00 & 18. & Stakeholders & 4.00 \\
\hline 4. & Knowledge Management & 17.00 & 19. & Teams & 4.00 \\
\hline 5. & Performance & 12.00 & 20. & Structural Configuration & 4.00 \\
\hline 6. & Innovation Process & 9.00 & 21. & Exploratory Innovation & 4.00 \\
\hline 7. & Resource Dependence Theory & 9.00 & 22. & $\begin{array}{l}\text { Ambidextrous } \\
\text { Interorganizational }\end{array}$ & 4.00 \\
\hline 8. & Knowledge Share & 9.00 & 23. & Leadership & 4.00 \\
\hline 9. & Start-ups & 8.00 & 24. & $\begin{array}{l}\text { Interorganizational } \\
\text { Collaboration }\end{array}$ & 4.00 \\
\hline 10. & Technology Management & 8.00 & 25. & Open Innovation & 4.00 \\
\hline 11. & Venture Performance & 7.00 & 26. & Strategic Performance & 3.00 \\
\hline 12 & Creativity & 7.00 & 27. & Suppliers & 3.00 \\
\hline 13. & Innovation Performance & 6.00 & 28. & Firms & 3.00 \\
\hline 14. & Human Capital & 6.00 & 29. & Corporate Performance & 3.00 \\
\hline 15. & Institutional Theory & 6.00 & 30. & Decision Making Process & 3.00 \\
\hline
\end{tabular}

Source: own elaboration.

Table 4 shows a comprehensive list of the most frequently used expressions in the data set for all periods (2009-2020), along with the concepts that are most commonly used and associated in research, which belong to the periods mentioned in Table 3.

\section{Findings}

The method used in this study refers to the classification prepared with co-word analysis. This method is simple and straightforward: the study considered each word separately and grouped the publications into three four-year periods according to these single words. If the classification by single words can explain the field differences correctly, it is more plausible for a phrase to produce meaningful results as well. Common word analysis was performed from 30 different journals from Web of Science. 
By integrating words with the same semantic structure, we eliminated more than tens of thousands of useless words in the data set. As a result, only the most commonly used structures of words were considered.

This study has a unique value for the literature. A similar study by Leydesdorff (1997) conducted a similar co-word analysis in the field of biochemistry to categorize publications into broad categories such as theoretical and empirical. The author indicates that the same word can have different meanings in different contexts, so confusion is inevitable. Our work covered all fields of management, organization, and business science. Therefore, the findings of our study are more consistent and better defend against such confusion.

One of the methods that researchers often prefer in bibliometrics is co-word analysis. Co-word analysis consists of several stages. It is known that it is also related to the field of text mining. For the success of this method, if it is usually aimed to determine periodic changes or trends, trend analysis should be applied. In the trend analysis visualization, the most frequently repeated words are shown with correspondence analysis, meaning that the words related to the researched management issues - along with the structural social capital elements - are revealed according to their periods. Considering the most studied subjects among the words evaluated in Table 3, we saw that the order of the words changes according to the periods' changes. Considering the main topics of the three periods of our research, it is unsurprising that there are similarities, namely the words that rank among the top in each period are "innovation," "entrepreneurship," "knowledge management," "performance," "leadership,” "technology," and "human resources."

According to the findings for the period 2009-2020 considered in the study (Table 4), we see that similar findings emerged but the order changed. We see that the themes of "entrepreneurship," "human resources," "innovation," "knowledge management," and "performance management" are the most prominent. The position of structural social capital elements in the management or organization research - accessing the complex, new, and costly information required to create new products that better respond to customer needs - uncover new knowledge acquisition and knowledge recombination that can lead to innovation and help businesses acquire new knowledge (Henderson and Clark, 1990; Inkpen and Tsang, 2005; Alguezaui and Filieri, 2010).

There may be some limitations to this study regarding the results obtained. Without considering or comparing the effects of the other two dimensions - relational and cognitive - focusing only on structural social capital and investigating the effects in 
the existing management and organization literature will allow for the number of such studies to increase.

\section{Discussion}

This research focuses on structural social capital that includes all social interaction in the network, which is related to the social bond patterns that characterize group actors, the characteristics of the social system, and the network of relationships as a whole. According to the literature, there are many findings that show structural social capital improves the results of knowledge transfer and innovation, facilitates the flow of information, allows influence on network members, reinforces abilities to access resources, and helps to gain recognition as a social group member who shares similar interests and resources with other members (see Lin, 2001; Uzzi, 1996).

The main reason for grouping these findings in detail periodically and according to their subjects was to prevent the work of structural social capital - which is the dimension of social capital that focuses on the essence of relations - around the same axis and to reveal the same or similar findings in a narrow area. From this perspective, it was important to make this study and determine the basic managerial issues so as to reveal the least researched or related topics or statements. Therefore, we believed that such a study will provide multiple benefits and advantages in determining understudied subjects and in associating them with research topics that are important and beneficial but are rarely mentioned. The debate in this research arises from the need to reveal which management and organization issues prioritize structural social capital to enable some advantages that would be unachievable in their absence.

\section{Conclusion}

After scanning the enormous number of data sets with KH Coder software - developed especially for text mining - we compared data by years based on averages and frequencies. Our study shows the most intriguing managerial topic trends during 2009-2020. After co-word analysis, we created a co-word matrix then elaborated with Ucinet 6 software (Borgatti et al., 2002). All the major terms with high frequency were visualized after extracting data to explore research hotspots for structural social capital. We were able to reveal the connection between major terms and high-frequency themes by referring to clustering. We tested whether articles that contain a specific keyword have comparable performance to articles that contain the same word in their titles 
and abstracts. By showing interrelated concepts and subjects that affect each other, subject orientations in articles in each period were grouped and periodic differences of the subjects were determined. As a result, we see that the main themes in the studies about structural social capital in the management and organizational science literature do not differ significantly over time, with few exceptions. When the periods are compared, we learned that the subjects repeat every period the same few rarely encountered management and organization concepts.

\section{References}

Acquaah, M., Amoako-Gyampah K. and Nyathi, N.Q. (2014). Measuring and valuing social capital: A Systematic Review. Network for Business Sustainability South Africa, 1-96. Obtained from: nbs.net/knowledge.

Adler, P.S. and Kwon, S.W. (2002). Social Capital: Prospects for a New Concept. Academy Of Management Review, 27(1), 17-40. http://dx.doi.org/10.2307/4134367.

Agampodi, T.C., Agampodi, S.B., Glozier, N. and Siribaddana, S. (2015). Measurement of social capital in relation to health in low and middle income countries (LMIC): A systematic review. Social Science \& Medicine, 128, 95-104. http://dx.doi.org/10.1016/j.socscimed.2015.01.005.

Ahuja, G. (2000). Collaboration networks, structural holes, and innovation: a longitudinal study. Administrative Science Quarterly, 45(3), 425-455. http://dx.doi.org/10.2307/2667105.

Alguezaui, S. and Filieri, R. (2010). Investigating the role of social capital in innovation: Sparse versus dense network. Journal of Knowledge Management, 14(6), 891-909. http://dx.doi.org/10.1108/13673271011084925.

Alan, H. and Sözen, C. (2017). The Role of Formal and Informal Social Networks in Social Capital Acquisition: An Investigation on Women Board Directors. Journal of Business Research Turk, 9(1), 339-361. http://dx.doi.org/10.20491/isarder.2017.248.

Anderson, A.R., and Jack, S.L. (2002). The articulation of social capital in entrepreneurial networks: A glue or lubricant? Entrepreneurship and Regional Development, 14, 193-210. http://dx.doi.org/10.1080/08985620110112079.

Berkman, L.F. and Glass, T. (2000). Social integration, social networks, social support, and health. In: L.F. Berkman and I. Kawachi (eds.), Social Epidemiology (pp. 137-173). New York: Oxford University Press.

Bolino, M., Turnley, W., and Bloodgood, J.M. (2002). Citizenship behavior and the creation of social capital in organizations. Academy of Management Review, 27(4), 505-522. http://dx.doi.org/10.5465/amr.2002.7566023.

Bourdieu, P. (1983). Ökonomisches Kapital, Kulturelles Kapital, Soziales Kapital, R. Kreckel (ed.), Soziale Ungleichheit, Soziale Welt. Sonderband 2. Göttingen.

Bourdieu, P. (1986). The forms of capital. In: J.G. Richardson (ed.), Handbook of theory and research for the sociology of education. New York: Greenwood.

Bouty, I. (2000). Interpersonal and interaction influences on informal resource exchanges between R\&D researchers across organizational boundaries. Academy of Management Journal, 43(1), 50-65. http://dx.doi.org/10.5465/1556385.

Burt, R.S. (1992). Structural Holes: The Social Structure of Competition, Cambridge, MA: Harvard University Press. 
Burt, R.S. (2001). Structural holes versus network closure as social capital. In: N. Lin, K. Cook, R.S. Burt (eds.), Social Capital: Theory and Research. 31-56. New York: Aldine De Gruyter.

Chung, S., Singh, H, and Lee, K. (2000). Complementarity, status similarity and social capital as drivers of alliance formation. Strategic Management Journal, 21(1), 1-22. http://dx.doi.org/10.1002/(SICI)1097-0266(200001)21: 1\%3C1::AID-SMJ63\%3E3.0.CO;2-P.

Cobo, M.J., López-Herrera, A.G., Herrera-Viedma, E., and Herrera, F. (2011). Science mapping software tools: Review, analysis, and cooperative study among tools. Journal of the American Society for Information Science and Technology, 62(7), 1382-1402. http://dx.doi.org/10.1002/asi.21525.

Coleman, J.S. (1988). Social capital in the creation of human capital. American Journal of Sociology, 94 , 95-120. http://dx.doi.org/10.1093/oso/9780195159509.003.0007.

DeFilippi, R. and Arthur, M. (1998). Paradox in project-based enterprises: The case of filmmaking. California Management Review, 40(2), 125-140. http://dx.doi.org/10.2307/41165936.

DeSilva, M.J., McKenzie, K., Harpham, T. and Huttly, S.R.A. (2005). Social capital and mental illness: A systematic review. Journal of Epidemiology \& Community Health, 59(8), 619-627. http://dx.doi.org/10.1136/jech.2004.029678.

Donthu, N., Kumar, S., and Pattnaik, D. (2020). Forty-five years of Journal of Business Research: A bibliometric analysis. Journal of Business Research, 109, 1-14. http://dx.doi.org/10.1016/j.jbusres.2019.10.039.

Ehlen, C., van der Klink, M., Roentgen, U. et al. (2014). Knowledge Productivity for Sustainable Innovation: Social Capital as HRD Target. European Journal of Training $\&$ Development, 38(1/2), 54-74. http://dx.doi.org/10.1108/EJTD-10-2013-0119.

Ell, K. (1984). Social networks, social support, and health status: A review. Social Service Review, 58(1), 133-149. http://dx.doi.org/10.1086/644168.

Fukuyama, F. (1995). Trust: The social virtues and the creation of prosperity. New York: Free Press.

García-Villaverde, P.M., Parra-Requena, G. and Molina-Morales, F.X. (2018). Structural social capital and knowledge acquisition: implications of cluster membership, Entrepreneurship \& Regional Development, 30(5-6), 530-561. http://dx.doi.org/10.1080/08985626.2017.1407366.

Gargiulo, M, and Benassi, M. (2000). Trapped in your own net? Network cohesion, structural holes and the adaptation of social capital. Organization Science, 11(2), 183-196. http://dx.doi.org/10.1287/orsc.11.2.183.12514.

Goutam, C., Murali, P. and Statish, G. (2013). Text Mining Analysis, Practical Methods, Examples, and Case Studies using SAS. SAS Press.

Granovetter, M. (1973). Strength of Weak Ties. American Journal of Sociology, 78, 1360-1380. http://dx.doi.org/10.1016/B978-0-12-442450-0.50025-0.

Granovetter, M. (1985). Economic Action and Social Structure: The Problem of Embeddedness. American Journal of Sociology, 91(3), 481-510. http://dx.doi.org/10.1002/9780470755679.ch5.

Greenacre, M.J. (1994). Correspondence Analysis and its Interpretation. In: J. Blasius and M.J. Greenacre (eds.), Correspondence Analysis in the Social Sciences: Recent Development and Applications. London: Academic Press Inc.

Gulati, R. (1995). Social Structure and Alliance Formation Patterns, A Longitudinal Analysis. Administrative Science Quarterly, 40, 619-652. http://dx.doi.org/10.2307/2393756.

Gulati, R. (1998). Alliances and networks. Strategic Management Journal, 19(4), 293-317. http://dx.doi.org/10.1002/(SICI)1097-0266(199804)19: 4\%3C293::AID-SMJ982\%3E3.0.CO;2-M.

Gulati, R., Dialdin, D.A. and Wang, L. (2002). Organizational networks. In: J.A.C. Baum (eds.), The Blackwell Companion to Organizations. Oxford: Blackwell. 
Hakansson, H. and Ford, D. (2002). How should companies interact in business networks?, Journal of Business Research, 55, 133-139. http://dx.doi.org/10.1016/S0148-2963(00)00148-X.

He, Q. (1999). Knowledge discovery through co-word analysis. Library Trends, 48(1), 133-159. http://hdl.handle.net/2142/8267.

Henderson, R.M. and Clark, K.B. (1990). Architectural innovation: The reconfiguration of existing product technologies and the failure of established firms. Administrative Science Quarterly, 35(1), 9-30. http://dx.doi.org/10.2307/2393549.

Hoffman, D.L. and Franke, G.R. (1986). Correspondence Analysis: Graphical Representation of Categorical Data in Marketing Research, Journal of Marketing Research, 23(3), 213-227. http://dx.doi.org/10.2307/3151480.

Huggins, R. and Johnston, A. (2010). Knowledge Flow and Inter-Firm Networks: The Influence of Network Resources, Spatial Proximity, and Firm Size, Entrepreneurship and Regional Development, 22(5), 457-484, https://doi.org/10.1080/08985620903171350.

Inkpen, A. and Tsang, E.W.K. (2005). Social capital networks and knowledge transfer. Academy of Management Review, 30(1), 146-165. http://dx.doi.org/10.5465/amr.2005.15281445.

Jia, X. Dai, T. and Guo, X. (2014). Comprehensive exploration of urban health by bibliometric analysis: 35 years and 11,299 articles. Scientometrics, 99(3), 881-894. http://dx.doi.org/10.1007/s11192-013-1220-4.

Koseoglu, M.A. (2016). Growth and structure of authorship and co-authorship network in the strategic management realm: Evidence from the Strategic Management Journal. BRQ Business Research Quarterly, 19(3), 153-170. http://dx.doi.org/10.1007/s11192-013-1220-4.

Kroonenberg, P.M. and Greenacre, M.J. (2005). Correspondence analysis. In: S. Kotz, C.B. Read, N. Balakrishnan, B. Vidakovic (eds.), Encyclopedia of Statistical Sciences, 1394-1403. New York: Wiley.

Lehner, O.M. (2014). The formation and interplay of social capital in crowdfunded social ventures. Entrepreneurship \& Regional Development, 26(5-6), 478-499.

Leydesdorff, L. (1997). Why words and co-words cannot measure the development of the sciences. Journal of the American Society for Information Science, 48(5), 418-427. https://doi.org/10.1002/(SICI)1097-4571(199705)48: 5<418::AID-ASI4>3.0.CO;2-Y.

Li, F., Li, M., Guan, P., Ma, S., and Cui, L. (2015). Mapping publication trends and identifying hot spots of research on internet health information seeking behavior: a quantitative and co-word biclustering analysis. Journal of Medical Internet Research, 17(3). http://dx.doi.org/10.2196/jmir.3326.

Lin, N. (1999). Social networks and status attainment. Annual Review of Sociology, 25, 467-487. http://dx.doi.org/10.4324/9780429494468-62.

Lin, N. (2001). Social capital: A theory of social structure and action. Cambridge, MA: Cambridge University Press.

Nahapiet, J. and Ghoshal, S. (1998). Social capital, intellectual capital, and the organizational advantage, The Academy of Management Review, 23(2), 242-266. http://dx.doi.org/10.2307/259373

Nyqvist, F., Forsman, A.K., Giuntoli, G. and Cattan, M. (2012). Social capital as a resource for mental well-being in older people: A systematic review. Aging \& Mental Health, 17(4), 394-410. http://dx.doi.org/10.1080/13607863.2012.742490.

Partanen, J., Möller, K., Westerlund, M. et al. (2008). Social Capital in the Growth of Science-and-Technology-Based Smes. Industrial Marketing Management, 37(5), 513-522.

http://dx.doi.org/10.1016/j.indmarman.2007.09.012.

Perry-Smith, J.E. and Shalley, Ch.E. (2003). The Social Side of Creativity: A Static and Dynamic Social Network Perspective. The Academy of Management Review, 28(1), 89-106. http://dx.doi.org/10.2307/30040691. 
Powell, W.W., Koput, K.W. and Smith-Doerr, L. (1996). Interorganizational collaboration and the locus of innovation: Networks of learning in biotechnology. Administrative Science Quarterly, 41(1), 116-145. http://dx.doi.org/10.2307/2393988.

Putnam, R.D. (1993). The prosperous community: social capital and public life. The American Prospect, 4, 35-42.

Putnam, R.D. (1995). Bowling alone: America’s declining social capital. Journal of Democracy, 6(1), 65-78. http://dx.doi.org/10.1353/jod.1995.0002.

Seung-Hyun, R. and Leonardi, P.M. (2014). Networks, Attention, and Good Ideas: Taking Advantage of Social Structure. Academy of Management Annual Meeting Proceedings. https://doi.org/10.5465/ambpp.2014.66.

Sargut, A.S. (2006). Social capital: enabling structures or purposive action? Akdeniz İ.̇.B.F. Dergisi, $6(12), 1-13$.

Stevenson, W.B. and Greenberg, D. (2000). Agency and social networks: Strategies of action in a social structure of position, opposition and opportunity. Administrative Science Quarterly, 45, 651-678. http://dx.doi.org/10.2307/2667015.

Su, H.N. and Lee, P.C. (2010). Mapping knowledge structure by keyword co-occurrence: a first look at journal papers in Technology Foresight. Scientometrics, 85(1), 65-79. http://dx.doi.org/10.1007/s11192-010-0259-8.

Tsai, W. (2009). Social Capital, Strategic Relatedness and the Formation of Intraorganizational Linkages. Strategic Management Journal, 21(9), 925-939. http://dx.doi.org/10.1002/1097-0266(200009)21: 9\%3C925::AID-SMJ129\%3E3.0.CO;2-I.

Uzzi, B. (1996). The sources and consequences of embeddedness for the economic performance of organizations: the network effect. American Sociological Review, 61(4), 674-698. http://dx.doi.org/10.17323/1726-3247-2007-4-43-59.

Uzzi, B. (1997). Social structure and competition in interfirm networks: The paradox of embeddedness. Administrative Science Quarterly, 42(1), 35-67. http://dx.doi.org/10.2307/2393808.

Walker, G., Kogut, B., and Shan, W. (1997). Social capital, structural holes and the formation of an industry network, Organization Science, 8, 109-125. http://dx.doi.org/10.1287/orsc.8.2.109.

Zupic, I. and Cater, T. (2015). Bibliometric methods in management and organization. Organizational Research Methods, 18(3), 429-472. http://dx.doi.org/10.5465/ambpp.2013.13426abstract. 